\title{
ROCK PHOSPHATE SOLUBILIZING MICROORGANISMS ISOLATED FROM MAIZE RHIZOSPHERE SOIL
}

\section{ELIANE APARECIDA GOMES ${ }^{1}$, UBIANA DE CÁSSIA SILVA², IVANILDO EVODIO MARRIEL ${ }^{1}$, CHRISTIANE ABREU DE OLIVEIRA ${ }^{1}$ and UBIRACI GOMES DE PAULA LANA ${ }^{1}$}

\author{
${ }^{1}$ Embrapa Maize and Sorghum, Sete Lagoas, MG, Brazil, eliane.a.gomes@embrapa.br, ivanildo.marriel@embrapa.br, \\ christiane.paiva@embrapa.br, ubiraci.lana@embrapa.br \\ ${ }^{2}$ Federal University of Viçosa, Viçosa, MG, Brazil, ubiana@yahoo.com.br
}

Revista Brasileira de Milho e Sorgo, v.13, n.1, p. 69-81, 2014

\begin{abstract}
The selection of microorganisms capable of solubilizing phosphorus (P) from rock phosphates (RP) may contribute to reduce the dependence of imported fertilizers in grain crops, reducing the costs of agricultural production, and also the environmental impacts. This study tested 59 microorganisms (46 bacteria and 13 fungi) isolated from maize rhizosphere for solubilization of two RP, Araxá and Itafós phosphate in vitro (PA and PI, respectively). Among the 59 microorganisms solubilizing PA, $51 \%$ of the bacteria and $8 \%$ of fungi were classified as efficient. For PI, among 18 isolates, $50 \%$ of the bacteria and no fungi were efficient. There were significant differences in the availability of $\mathrm{P}$ among strains for both phosphates and most isolates evaluated for both types of rocks released more soluble P from PI than PA. Bacterial isolates CMSB58, CMSB32, CMSB20 and CMSB46 solubilized almost 20\% of the P total in the PA and CMSB58, CMSB82, CMSB91 and CMSB48 solubilized more than 25\% of the PI. The solubilizing activity of both phosphates was associated with a reduction of $\mathrm{pH}$ which suggests that the acidification of the culture medium can be one of the mechanisms involved in the solubilization of P. There was a dominance of the genera Burkholderia and Bacillus in the group of the most efficient bacteria and Talaromyces and Penicillium in the fungi group. The contribution of these strains to increasing the phosphorus nutrition of grain crops should be investigated further by in vivo experiments.
\end{abstract}

Key words: Biosolubilization; Phosphorus; Zea mays; Araxá phosphate; Itafós phosphate.

\section{MICRORGANISMOS SOLUBILIZADORES DE FOSFATO DE ROCHA ISOLADOS DA RIZOSFERA DE MILHO}

RESUMO - A seleção de microrganismos capazes de solubilizarem fósforo (P) a partir de fosfatos de rocha (FR) pode contribuir para reduzir a dependência de fertilizantes importados em culturas de grãos, reduzindo os custos da produção agrícola e também os impactos ambientais. Este estudo avaliou 59 microrganismos (46 bactérias e 13 fungos), isolados da rizosfera de milho, quanto à solubilização de dois FR, Araxá e Itafós in vitro (FA e FI, respectivamente). Entre os 59 microrganismos solubilizadores de PA, $51 \%$ das bactérias e $8 \%$ dos fungos foram classificados como eficientes. Para FI, entre 18 isolados, 50\% das bactérias e nenhum fungo foram eficientes. Houve diferença significativa na disponibilidade de $\mathrm{P}$ entre as cepas em ambos os fosfatos e a maioria dos isolados avaliados em ambos os tipos de rocha liberaram mais P solúvel de FI em comparação com FA. As bactérias CMSB58, CMSB32, CMSB20 e CMSB46 solubilizaram quase 20\% do P total em FA e CMSB58, CMSB82, CMSB91 e CMSB48 solubilizaram mais que $25 \%$ de FI. A atividade de solubilização para ambos os fosfatos foi associada com a redução de $\mathrm{pH}$, sugerindo que a acidificação do meio de cultura pode ser um dos mecanismos envolvidos na solubilização de P. Houve predominância dos gêneros Burkholderia e Bacillus no grupo de bactérias mais eficientes e Talaromyces e Penicillium no grupo dos fungos. A contribuição destes isolados na melhoria da nutrição de $\mathrm{P}$ em milho precisa ser investigada futuramente em experimentos in vivo.

Palavras-chave: Biossolubilização; Fósforo; Zea mays; fosfato de Araxá; fosfato de Itafós. 
One of the limiting factors in tropical agriculture soils such as the Oxisol of the Brazilian acid savannas (Cerrado), is the low $\mathrm{pH}$ and the high phosphorus (P) fixation capacity of the soil, resulting in low availability of this nutrient to plants (Novais \& Smyth, 1999). Phosphorus is one of the most limiting macronutrients for agricultural production in many soils of the world as the overall efficiency of applied fertilizer can be less than 10\% (Baligar et al., 2001). P deficiency is generally alleviated through application of $\mathrm{P}$ fertilizers. However only a small portion of these is used by plants and the most $\mathrm{P}$ fertilizer readily form insoluble complexes with the constituents of the soil, becoming unavailable to plants, which leads to the need for frequent applications of this nutrient (Novais \& Smyth, 1999). Furthermore, the production of chemical fertilizers requires fossil energy for processing, transportation and distribution, which increases the production costs and environmental risks (Schröder et al., 2010).

In this context, the use of natural rock phosphate (RP) as $\mathrm{P}$ source for crops has been evaluated. The application of RP as fertilizer in tropical environments has numerous advantages, especially in the rate of dissolution of these rocks, and the reaction between mineral surfaces and soil solution, which are intensified with temperature and humidity present in these soils (Van Straaten, 2006). However, depending on the properties of the RP, the soil, climatic conditions, crop and on management practices (Sale \& Mokwunye, 1993), it could take up to $4 \mathrm{yr}$ of annual application before RP treatments become as effective as super-phosphate (Ghani et al., 1994). The direct use of natural sources of $P$ as fertilizer, mainly for annual crops is not economically viable, particularly in soils with high adsorption and low ion exchange capacity (Simpson et al., 1997), as the Brazilian Cerrado soils.

For these reasons, various strategies have sought the use of microorganisms with potential for RP solubilization (Rajapaksha et al., 2011) to increase the availability of this nutrient from different types of phosphates of low solubility (Oliveira et al., 2009; Singh \& Reddy, 2011), reducing the cost and energy loss for the agronomic use of these sources of P (Mohammadi, 2012). The great advantage of this combined use, in addition to the exploration of alternative sources for P fertilization (Khan et al., 2007), is the use of rocks that have low levels of $\mathrm{P}$, which are inadequate for the fertilizer industry because they contain a high degree of impurities, such as marginal rocks and wastes from industry.

The key mechanism associated with solubilization of mineral phosphates is the reduction of the $\mathrm{pH}$ of the medium by the release of low molecular weight organic acids by microorganisms (Chung et al. 2005; Barroso \& Nahas, 2008; Gulati et al. 2010). These organic acids act removing inorganic $P$ from soil particles of clay either by direct exchange as chelation of metal ions in complex P-cations (Rodríguez \& Fraga, 1999). The release of anions also results in the rhizosphere acidification, directly increasing the solubility of inorganic precipitated salts of P. However, the soil microorganisms show wide variation in their ability to secrete organic acids and thus solubilize mineral phosphate (Richardson et al., 2009).

The recommendation of strains as inoculants able to solubilize $\mathrm{P}$ depends on the type of RP. Oliveira et al. (2009) isolated microorganisms capable of solubilizing organic and inorganic insoluble sources of $\mathrm{P}$ from the rhizosphere of maize genotypes efficient in the use of P. However, in that 
work, the focus was the solubilization of inorganic synthetic phosphate, such as tricalcium phosphate and aluminum phosphate, and the solubilizing potential of different natural RP from Brazilian natural mines by these microorganisms has not been evaluated.

In this paper, the main goal is to evaluate, among the microorganisms assessed by Oliveira et al. (2009), those isolates with potential to solubilize Brazilian natural RP to use as a source of P for grain crops.

\section{Materials and Methods}

Isolates of bacteria and fungi, belonging to the collection of multifunctional microorganisms of Embrapa Maize and Sorghum, were evaluated for their ability to solubilize two natural phosphates, named Araxá (PA) and Itafós (PI), extracted from RP mines in Brazil. Most microbial isolates were obtained from samples of rhizosphere soil of maize genotypes contrasting for $\mathrm{P}$ use efficiency under different soil management systems in the Brazilian Cerrado soil (Oliveira et al., 2009). The microorganisms were conserved in mineral oil and reactivated growing on PDA plates (200 $\mathrm{g} \mathrm{l}^{-1}$ of potato, $20 \mathrm{~g} \mathrm{l}^{-1}$ of dextrose and $15 \mathrm{~g} \mathrm{l}^{-1}$ of agar), using the method of streaking for obtaining pure colonies.

In order to evaluate the potential of $\mathrm{P}$ solubilization by the selected microorganisms, the NBRIP liquid culture medium was used (10 $\mathrm{g} \mathrm{l}^{-1}$ glucose, $0.15 \mathrm{~g} \mathrm{l}^{-1}$ of $\left(\mathrm{NH}_{4}\right)_{2} \mathrm{SO}_{4}, 0.2 \mathrm{~g} \mathrm{l}^{-1}$ of $\mathrm{KCl}, 5$ $\mathrm{g} \mathrm{l}^{-1}$ of $\mathrm{MgCl}_{2} .6 \mathrm{H}_{2} \mathrm{O}$ and $0.25 \mathrm{~g} \mathrm{l}^{-1}$ of $\mathrm{MgSO}_{4} \cdot 7 \mathrm{H}_{2} \mathrm{O}$ ) (Nautiyal, 1999) plus $5 \mathrm{~g} \mathrm{l}^{-1} \mathrm{PA}$ or PI, both containing approximately $24 \%$ of $\mathrm{P}_{2} \mathrm{O}_{5}$.

The experimentto evaluate the bioavailability of $\mathrm{P}$ from PA in vitro was a completely randomized design with three replications. Each plot consisted of a $250 \mathrm{ml}$ Erlenmeyer flask containing $50 \mathrm{ml}$ of culture medium plus RP. The treatments were 59 microorganisms individually inoculated into the culture medium (46 bacteria and 13 fungi). Also, one control containing only the culture medium and the other one with the culture medium and PA were included. In order to assess the potential of PI solubilization, 18 microorganisms were randomly selected using the same experimental model.

The microorganisms were inoculated separately, using $5 \times 10^{7}$ cells per $\mathrm{ml}$ of the bacterial suspension or five disks of $8 \mathrm{~mm}$ of the mycelium of fungi and actinobacteria. The cultures were submitted to incubation for 10 days with constant shaking of $120 \mathrm{rpm}$ and a temperature of $28{ }^{\circ} \mathrm{C}$ (Oliveira et al., 2009 modified).

After 10 days of incubation, the cultures were centrifuged at $5000 \mathrm{x} \mathrm{g}$ for $10 \mathrm{~min}$, the supernatant was filtered using paper Whatman no 42 and the concentration of soluble $\mathrm{P}$ was determined by the Murphy \& Riley (1962) methodology. Additionally, the $\mathrm{pH}$ of the filtrate from all samples, including the controls, was determined.

In order to determine the relative efficiency of $\mathrm{P}$ solubilization of the isolates we determined the following expression: $\left(\mathrm{N}_{1}-\mathrm{N}_{2}\right) / \mathrm{N}_{3} \times 100$, in which $\mathrm{N}_{1}$ is the concentration of $\mathrm{P}\left(\mathrm{mg} \mathrm{l}^{-1}\right)$ in the presence of microorganism, $\mathrm{N}_{2}$ is the concentration of $\mathrm{P}\left(\mathrm{mg} \mathrm{l}^{-1}\right)$ in the absence of microorganism and $\mathrm{N}_{3}$ is the total $\mathrm{P}$ concentration $\left(\mathrm{mg} \mathrm{l}^{-1}\right)$ contained in the RP. Then the microorganisms were classified into three groups according to the isolates that showed the best performance in $\mathrm{P}$ solubilization: efficient (67-100\%), moderately efficient (35.5$67 \%)$ and inefficient (0-35.5\%). 
Bacterial genomic DNA was extracted from cultures incubated in LB medium at $37{ }^{\circ} \mathrm{C}$ for $24 \mathrm{~h}$, by the phenol/chloroform method (Ausubel et al., 1987) and amplified using the $16 \mathrm{~S}$ rDNA primers F968 and R1401 (Nubel et al., 1996). Fungi ITS (internal transcribed sequences) rDNA fragments were amplified by the primers ITS1 and ITS4 (White et al., 1990) from genomic DNA extracted according to the method of Raeder \& Broda (1985). PCR reaction was performed in a final volume of $50 \mu \mathrm{l}$ containing $20 \mathrm{ng}$ DNA, 10 $\mathrm{mM}$ Tris- $\mathrm{HCl} \mathrm{pH} 8.3,50 \mathrm{mM} \mathrm{KCl}, 2.5 \mathrm{mM} \mathrm{MgCl}_{2}$, $0.125 \mathrm{mM}$ dNTPs, $0.4 \mu \mathrm{M}$ primers, $1.5 \mathrm{U}$ of Taq DNA polymerase (Invitrogen, Carlsbad, CA, USA) and $1 \%(\mathrm{v} / \mathrm{v})$ formamide for analysis of bacteria or $0.2 \%(\mathrm{v} / \mathrm{v}) \mathrm{DMSO}$ for fungi. Amplification was performed using the following conditions: $94{ }^{\circ} \mathrm{C}$ for $2 \mathrm{~min}, 30$ cycles of $94{ }^{\circ} \mathrm{C}$ for $1 \mathrm{~min}, 55^{\circ} \mathrm{C}$ for $1 \mathrm{~min}, 72{ }^{\circ} \mathrm{C}$ for $2 \mathrm{~min}$, and a final extension of $72{ }^{\circ} \mathrm{C}$ for $10 \mathrm{~min}$ for bacteria. The amplification for the fungi was performed using the following conditions: 40 cycles of $94{ }^{\circ} \mathrm{C}$ for $1 \mathrm{~min}, 50{ }^{\circ} \mathrm{C}$ for 1 $\min , 72{ }^{\circ} \mathrm{C}$ for $90 \mathrm{sec}$, and a final extension of $72{ }^{\circ} \mathrm{C}$ for $7 \mathrm{~min}$. The reaction products were analyzed by electrophoresis on $1.2 \%(\mathrm{w} / \mathrm{v})$ agarose gel stained with ethidium bromide $\left(1 \mu \mathrm{g} \mathrm{ml}^{-1}\right)$ and displayed in the equipment Gel Logic 200 (KODAK Company, Rochester, NY).

The amplification products were removed from the gel, purified with the kit QIAquick Gel Extraction (Qiagen, Hilden, Germany) and sequenced using the kit Big Dye Terminator (Applied Biosystems, Foster City, CA) according to the recommendations of manufactures. Samples were analyzed in the automated sequencer ABI PRISM 3100 Genetic Analyzer (Applied Biosystems, Foster City, CA) and the sequences were compared with the GenBank (http://www.ncbi.nlm.nih.gov/) using the program Blast N (Altschul et al., 1997).

The data obtained for phosphate solubilizing activity and $\mathrm{pH}$ of microorganisms were subjected to ANOVA and means were compared by the Scott Knott test using the software SISVAR (Ferreira, 2008). The linear correlation (r) between solubilized phosphate in liquid media and $\mathrm{pH}$ was performed using Excel 2007 (Microsoft Corporation, Redmond, WA). The differences obtained at the level of $\mathrm{P} \leq 0.05$ were considered significant.

\section{Results and Discussion}

Among the 59 microorganisms solubilizing PA, $51 \%$ of the bacteria were classified as efficient, $13 \%$ classified as moderately efficient and 54\% classified as inefficient. Related to fungi, $8 \%$ were efficient, $23 \%$ were moderately efficient and 69\% were inefficient (Figure 1). For PI, 50\% of the bacteria obtained were efficient, $8 \%$ were moderately efficient and $42 \%$ were inefficient. In the group of fungi were observed only $33 \%$ of the strains classified as moderately efficient and $67 \%$ as inefficient (Figure 1).

A significant difference $(\mathrm{p} \leq 0.05)$ among the values of PA solubilized that ranged from 0.94 to $100.70 \mathrm{mg} \mathrm{P}^{-1}$ was shown in Table 1 . Among the bacteria, CMSB58 (Burkholderia) and CMSB32 (Bacillus) were the most efficient, providing 100.70 and $94.98 \mathrm{mg} \mathrm{P} \mathrm{1}^{-1}$, respectively. Among the fungi, the isolates that showed higher solubilizing capacity of PA were CMSF14 (Penicillium), CMSF102 and CMSF105 (Talaromyces) that solubilized 75.54, 55.70 and $54.83 \mathrm{mg} \mathrm{P} \mathrm{1}^{-1}$, respectively.

Similarly, the solubilization of PI showed significant variation $(\mathrm{p} \leq 0.05)$ among the 18 
strains examined, including fungi and bacteria. The highest solubilization of PI were observed in strains of the Burkholderia genus CMSB58, CMSB48 and CMSB82 resulting in the release of 153.11, 135.58 and $132.88 \mathrm{mg} \mathrm{P} \mathrm{l}^{-1}$ (Table 1), respectively. Regarding the solubilization capacity of fungi in PI, the best isolates were CMSF14 (Penicillium), CMSF105 (Talaromyces) and CMSF102 (Talaromyces), releasing 71.36, 66.55 and $45.24 \mathrm{mg}$ $\mathrm{P}^{-1}$, respectively (Table 1).

RP solubilization values similar to our results are common. Xiao et al. (2008) investigated the RP solubilizing by Candida krissii, Penicillium expansum and Mucor ramosissimus isolated from phosphate mines and observed that the maximum content of soluble $\mathrm{P}$ was $109.3 \mathrm{mg}^{-1}$ released by C. krissii, followed by P. expansum (104.5 $\left.\mathrm{mg} \mathrm{1}^{-1}\right)$ and $M$. ramosissimus $99.9 \mathrm{mg} \mathrm{l}^{-1}$. Rajapaksha et al. (2011) also studied six strains of bacteria isolates from rice rhizosphere and observed that the $\mathrm{P}$ solubilization varied from 50 to $150 \mathrm{mg} \mathrm{P}^{-1}$.

The genus Burkholderia has been reported in other studies as a plant growth-promoting rhizobacteria and as efficient in solubilizing P from different sources (Anandham et al., 2007; Marra et al., 2011; Peix et al., 2011; Azziz et al., 2012). It has been observed that this genus is associated in large numbers with the rhizosphere of maize, ranging from 4 to $35 \%$ of the total culturable bacteria present in the rhizosphere of this crop (Hebbar et al., 1994; Balandreau et al., 2001). Besides Burkholderia, the genera Bacillus and Paenibacillus along with Aspergillus, Penicillium and Talaromyces have been reported as P solubilizers, plant growth promotion and used as commercial $\mathrm{P}$ inoculants (Khan et al., 2008; Khan et al., 2010; Scervino et al., 2010; Naraghi et al., 2012; Anand et al., 2013; Junges et al., 2013; Murugappan et al., 2013).
All the strains that solubilized phosphate in liquid media reduced the $\mathrm{pH}$ of the media compared to the non-inoculated control, regardless of the source of phosphate. There was a significant and negative correlation between the amount of soluble phosphorus and the final $\mathrm{pH}$ of culture media $(r=-0.89$ for PI and $r=-0.82$ for PA; $p<$ 0.01) (Table 1).

The comparison of results of both types of phosphates showed that the solubilization of PI and PA were significantly different (Figure 2). The solubilization of PI was higher than PA by the isolates CMSB58, CMSB48, CMSB82, CMSB91, CMSB119, CMSB5, CMSB2, CMSF105 and CMSF80. Most of these isolates belong to Burkholderia genus. On the other hand, CMSB70, CMSB32, CMSB62, CMSF40, CMSB86 and CMSB124 showed opposite results, being efficient in the PA solubilization (between 18.62\% and $13.97 \%$ ), whereas they solubilized less than $3 \%$ of PI (Table 1), indicating the effect of the type of rock in this biological process (Figure 2). Interesting, all of these PA efficient isolates are from Bacillus and Arthrobacter genera and none of them belongs to the Burkholderia (Table 1 and Figure 2). In both PI and PA, the isolate CMSB58 presented the best performance in the solubilization, around 153.11 mg $\mathrm{P}^{-1}$ and $100.70 \mathrm{mg} \mathrm{P} \mathrm{l}^{-1}$ (29.20 and 19.17\% of the $\mathrm{P}$ total content, respectively), demonstrating potential of this isolate to be used to improve the $\mathrm{P}$ availability of these minerals being a good candidate for a biofertilizer to be used in maize fields.

Another explanation for this difference in the solubilization of both types of RP is the different physicochemical characteristics, depending on their source material and particle 


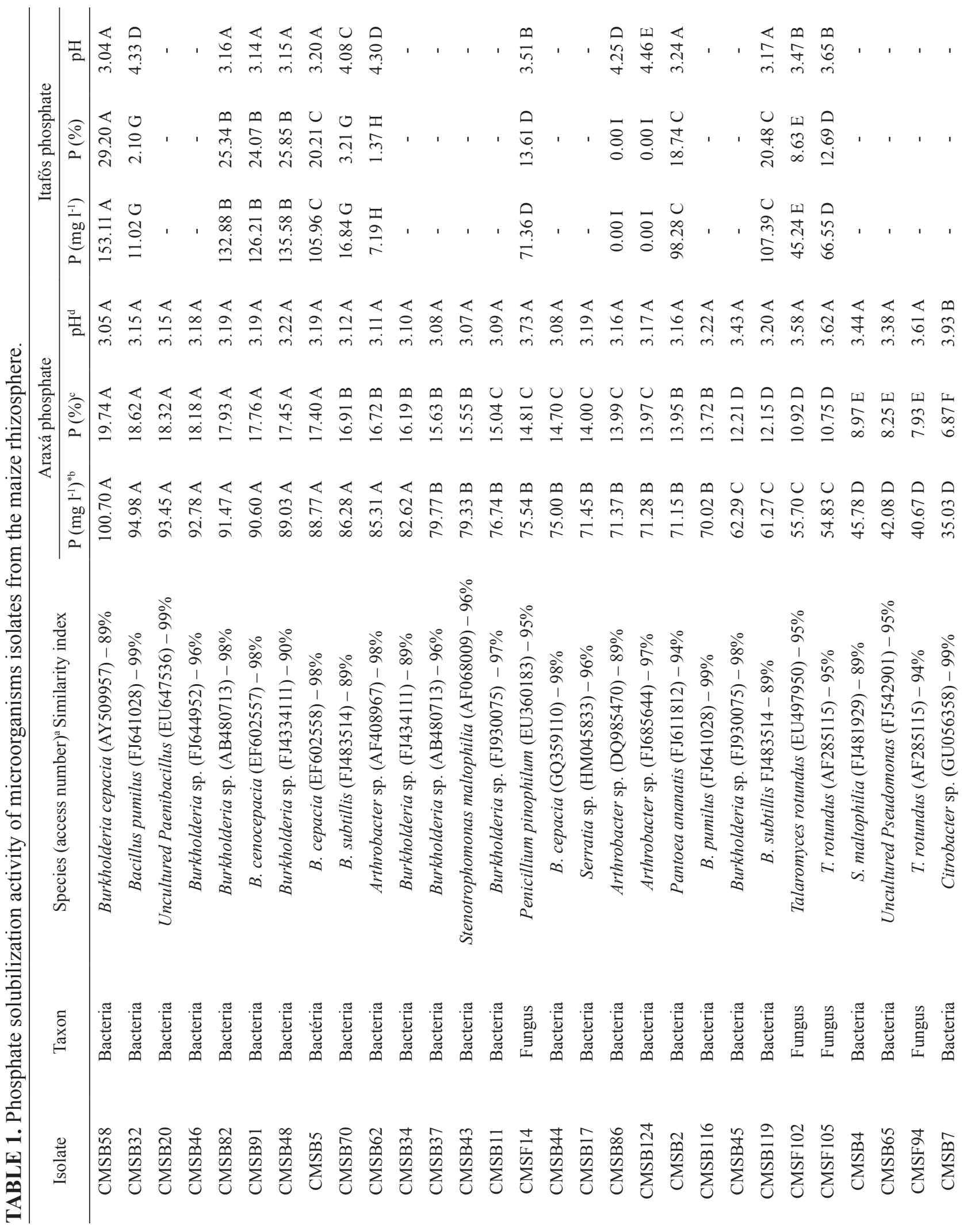




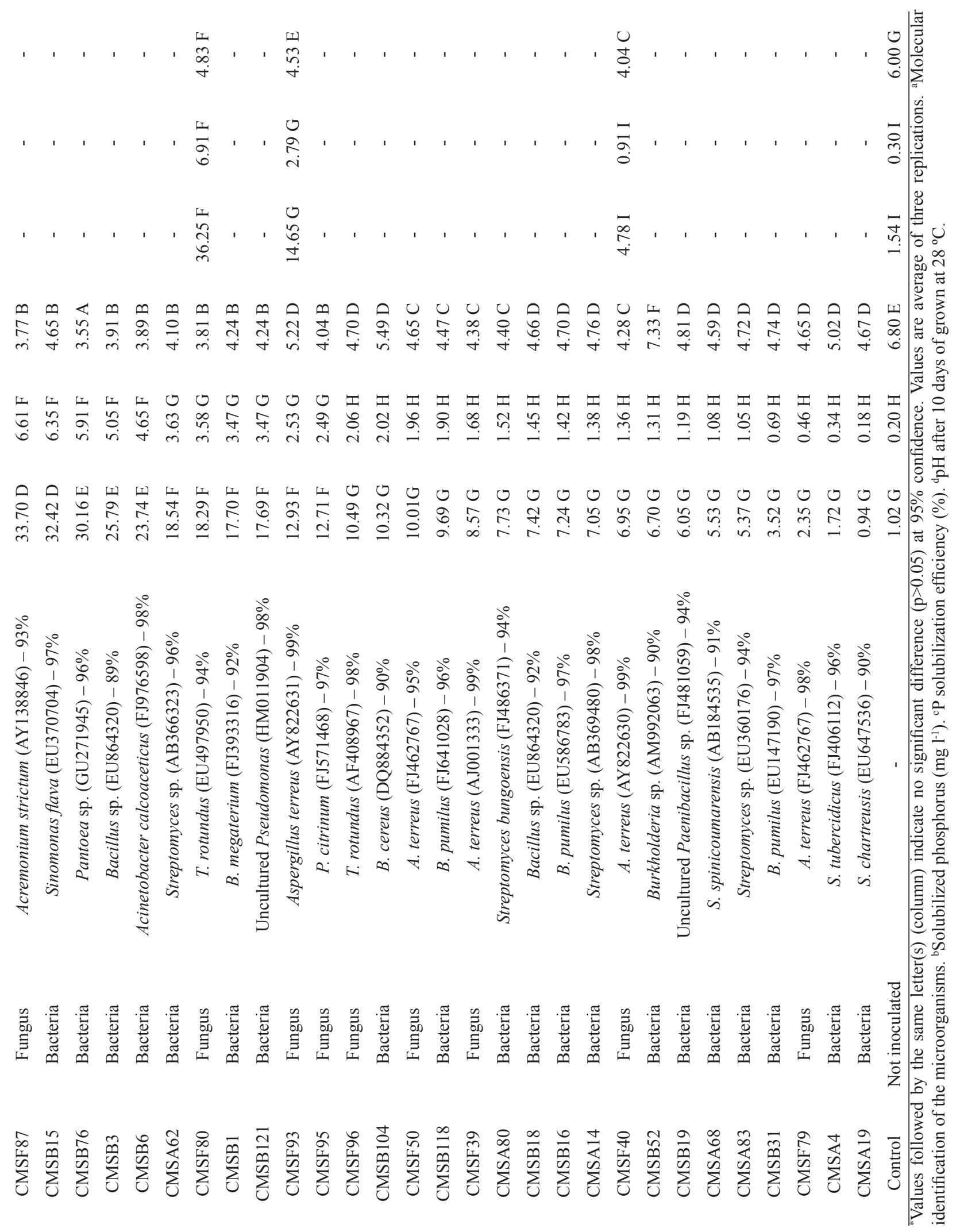




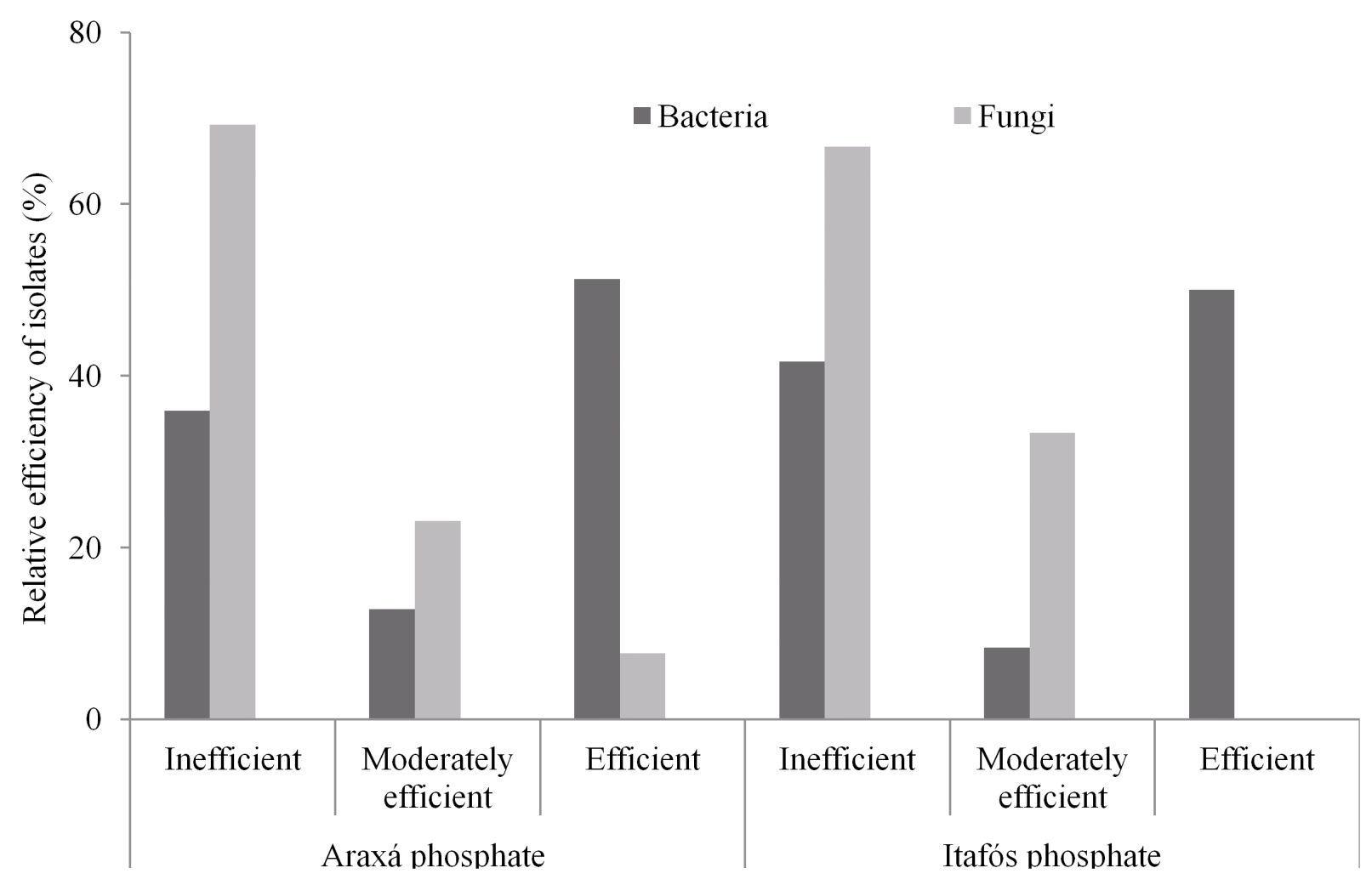

FIGURE 1. Relative efficiency of the isolates in the P solubilization (\%) of the Araxá and Itafós phosphates.

size, that influence their rate of solubilization (Loureiro et al., 2008). Mendes et al. (2013) showed that fluoride limited the solubilization of Araxá RP by A. niger by negatively affecting metabolic processes involved in phosphate solubilization, such as decreasing fungal growth, citric acid production and medium acidification. In the case of phosphates of sedimentary origin, such as PI, generally, there are higher contents of available $\mathrm{P}$ in relation to the ones of igneous or metamorphic origin, such as the PA that exhibits high crystallization level and low solubility in citric acid (Kliemann \& Lima, 2001). Due to these characteristics, there are significant differences compared to the natural bioavailability of nutrients, which can be altered in the presence of microorganisms (Richardson \& Simpson, 2011).
The differences observed in the present work according both type of RP can contribute to the process of selection of microorganisms to be used with natural phosphates in tropical agriculture. It can be suggested that for each type of rock to be used, there are different microorganisms that have potential for solubilizing $\mathrm{P}$.

Other authors also observed that solubilization capacity of microorganisms depends on the type of phosphate assessed. Xiao et al. (2008) observed that solubilization capacity of three types of RP from China by the fungi Candida krissii, Penicillium expansum and Mucor ramosissimus was directly proportional to the $\mathrm{P}$ content in the rock. In other words, it might be concluded that the capability of RP solubilization was positively correlated with the grade of RP. 
This paper presents a considerable improvement in the characterization of microorganisms that have potential for use for the production of inoculants to maize, since most microorganisms selected solubilize both types of RP from Brazilian natural mines and other inorganic sources, such as aluminum phosphate. Other isolates also have the ability to mineralize organic sources of $\mathrm{P}$, such as soy lecithin and phytate (Oliveira et al., 2009).

Together, these microorganisms should be evaluated in experiments in vivo in the future, using different RP and vehicles aiming the development of inoculants for $\mathrm{P}$ supply in agriculture applied in seeds or directly on soil to be offered to farmers as technological products for reduction of fertilizer costs and environmental impacts.

\section{Conclusions}

There were significant differences in the availability of $\mathrm{P}$ among strains and most isolates released more soluble $\mathrm{P}$ from $\mathrm{PI}$ than PA. The majority of the bacteria were efficient in the $\mathrm{P}$ solubilization of both RP. There was a negative correlation between the final $\mathrm{pH}$ of the culture medium and the concentration of soluble phosphate suggesting that the acidification of the culture medium can be one of the mechanisms involved in the solubilization of $\mathrm{P}$ by these microorganisms. There was a dominance of the genera Burkholderia and Bacillus in the group of the most efficient microorganisms and the contribution of these strains, isolated or in combination, to increase the $\mathrm{P}$ nutrition of maize crops should be investigated further, by in plant experiments in tropical soils.

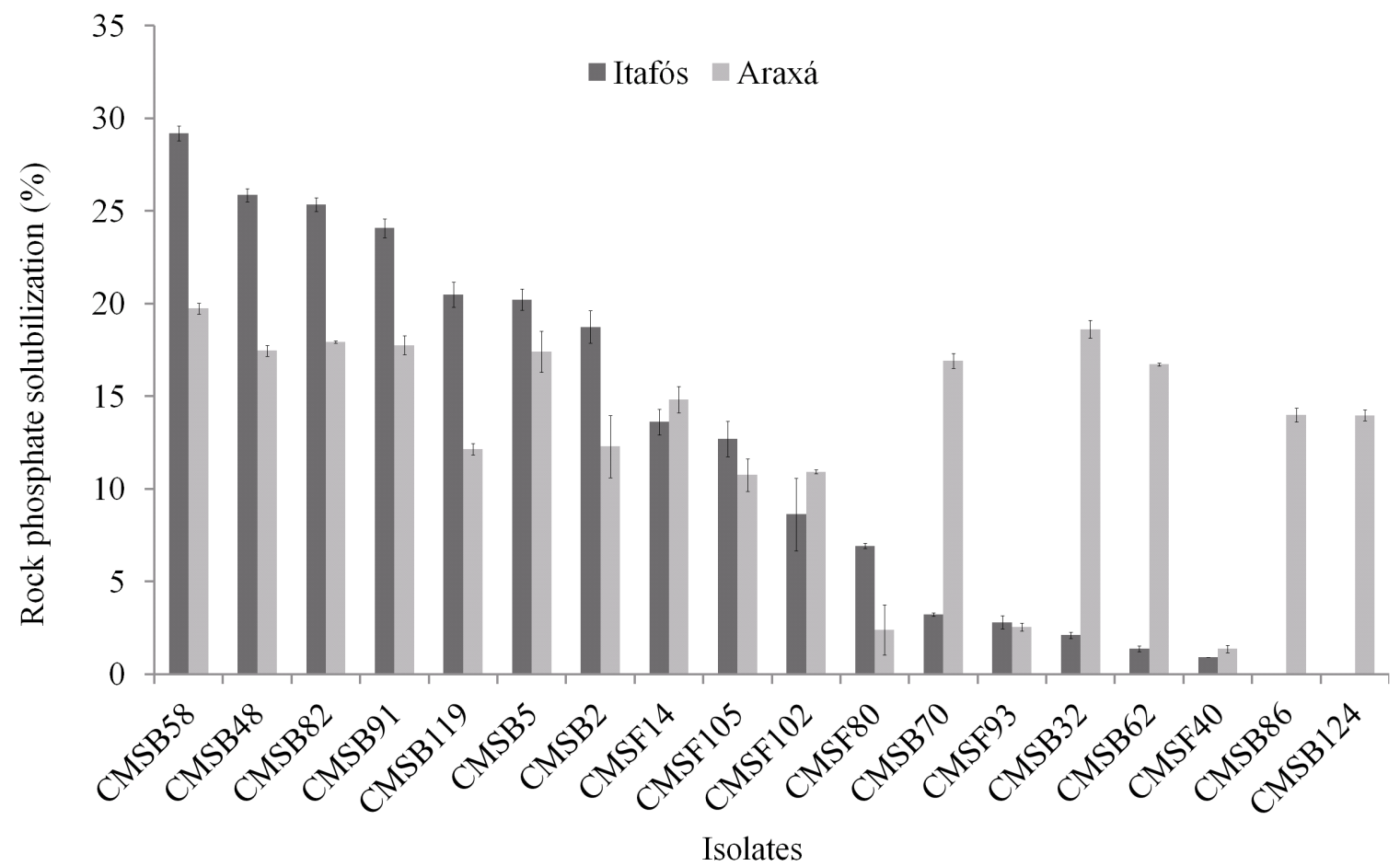

FIGURE 2. Percentage of Araxá and Itafós phosphate solubilization of 18 isolates of fungi and bacteria. Isolates identification is shown in Table 1. 


\section{Acknowledgments}

This work was supported by the Embrapa Maize and Sorghum, the Brazilian Council of Research and Scientific Development (CNPq) and the Foundation of Research Support of Minas Gerais State (Fapemig).

\section{References}

ALTSCHUL, S. F.; MADDEN, T. L.; SCHÄFFER, A. A.; ZHANG, J.; ZHANG, Z.; MILLER, W.; LIPMAN, D. J. Gapped BLAST and PSIBLAST: a new generation of protein database search programs. Nucleic Acids Research, Oxford, v. 25, p. 3389-3402, 1997.

ANANDHAM, R.; CHOI, K. H.; GANDHI, P. I.; YIM, W. J.; PARK, S. J.; KIM, K. A.; MADHAIYAN, M.; SA, T. M. Evaluation of shelf life and rock phosphate solubilization of Burkholderia sp. in nutrient-amended clay, rice bran and rock phosphate-based granular formulation. World Journal of Microbiology and Biotechnology, Oxford v. 23, p. 11211129, 2007.

AUSUBEL, F. M.; BRENT, R.; KINGSTON, R. E.; MOORE, D. D.; SIDEMAN, J. G.; SMITH, J.A.; STRUHL, K. Current Protocols in Molecular Biology. New York: J. Wiley, 1987.

AZZIZ, G.; BAJSA, N.; HAGHJOU, T.; TAULÉ, C.; VALVERDE, Á.; IGUAL, J. M.; ARIAS, A. Abundance, diversity and prospecting of culturable phosphate solubilizing bacteria on soils under crop-pasture rotations in a notillage regime in Uruguay. Applied Soil and Ecology, Amsterdam, v. 61, p. 320-326, 2012.
BALANDREAU, J.; VIALLARD, V.; COURNOYER, B.; COENYE, T.; LAEVENS, S.; VANDAMME, P. Burkholderia cepacia genomovar III is a common plant-associated bacterium. Applied and Environmental Microbiology, Washington, v. 67, p. 982-985, 2001.

BALIGAR, V. C.; FAGERIA, N. K.; HE, Z. L. Nutrient use efficiency in plants. Communication in Soil Science and Plant Analysis, New York, v. 32, p. 921-950, 2001. BARROSO, C. B.; NAHAS, E. Solubilização do fosfato de ferro em meio de cultura. Pesquisa Agropecuária Brasileira, Brasília, DF, v. 43, p. 529-535, 2008.

BROWNE, P.; RICE, O.; MILLER, S. H.; BURKE, J.; DOWLING, D. N.; MORRISSEY, J. P.; O'GARA, F. Superior inorganic phosphate solubilization is linked to phylogeny within the Pseudomonas fluorescens complex. Applied and Soil Ecology, Amsterdam,v. 43, p. 131-138, 2009.

CHEN, Y. P.; REKHA, P. D.; ARUN, A. B.; SHEN, F. T.; LAI, W. A.; YOUNG, C. C. Phosphate solubilizing bacteria from subtropical soil and their tricalcium phosphate solubilizing abilities. Applied and Soil Ecology, Amsterdam, v. 34, p. 33-41, 2006.

CHUNG, H.; PARK, M.; MADHAIYAN, M.; SESHADRI, S.; SONG, J.; CHO, H.; SA, T. Isolation and characterization of phosphate solubilizing bacteria from the rhizosphere of crop plants of Korea. Soil Biology and Biochemistry, Elmsford, v. 37, p. 1970-1974, 2005.

FERREIRA, D. F. SISVAR: um programa para análises e ensino de estatística. Revista 
Symposium, Lavras, v. 6, p. 36-41, 2008.

GHANI, A.; RAJAN, S. S. S.; LEE, A. Enhancement of phosphate rock solubility through biological processes. Soil Biology and Biochemistry, Elmsford, v. 26, p. 127-136, 1994.

GOLDSTEIN, A. H.; ROGERS, R. D.; MEAD, G. Mining by microbe. Biotechnology, Frankfurt, v. 11, p. 1250-1254, 1993.

GULATI, A.; VYAS, P.; RAHI, P.; KASANA, R. C. Plant growth promoting and rhizosphere competent Acinetobacter rhizosphere strain BIHB 723 from the cold desert of Himalayas. Current Microbiology, New York, v. 58, p. 371-377, 2009.

HEBBAR, K. P.; MARTEL, M. H.; HEULIN, T. Burkholderia cepacia, a plant growth promoting rhizobacterial associate of maize. In: RYDER, M. H.; STEPHENS, P. M.; BOWEN, G. D. (Ed.). Improving plant productivity with rhizosphere bacteria. Adelaide: Commonwealth Scientific and Industrial Research Organization, 1994. p. 201-203.

KHAN, M. S.; ZAIDI, A., WANI, P. A. Role of phosphate-solubilizing microorganisms in sustainable agriculture: A review. Agronomy for Sustainable Development, Paris, v. 27, p. 29-43, 2007.

KHAN, M. S.; ZAIDI, A.; AHEMAD, M.; OVES, M.; WANI, P. A. Plant growth promotion by phosphate solubilizing fungi - current perspective. Archives of Agronomy and Soil Science, London, v. 56, p. 73-98, 2010.

KLIEMANN, H. J., LIMA, D. V. Eficiência agronômica de fosfatos naturais e sua influência no fósforo disponível em dois solos de Cerrado. Pesquisa Agropecuária
Tropical, Goiânia, v. 31, p. 111-119, 2001.

LOUREIRO, F. E. L.; MONTE, M. B. M.; NASCIMENTO, M. Agrominerais - fosfato em rochas \& minerais industriais - usos e especificações. 2. ed. Rio de Janeiro: CETEM, 2008.

MARRA, L. M.; OLIVEIRA, S. M.; SOARES, C. R. F. S.; MOREIRA, F. M. S. Solubilization of inorganic phosphates by inoculant strains from tropical legumes. Scientia Agricola, Piracicaba, v. 68, p. 603-609, 2011.

MENDES G. O.; VASSILEV, N. B.; BONDUKI, V. H.; SILVA, I. R. da; RIBEIRO JR., J. I.; COSTA, M. D. Inhibition of Aspergillus niger phosphate solubilization by fluoride released from rock phosphate. Applied Environmental Microbiology, Washington, v. 79, p.4906-4913, 2013.

MOHAMMADI, K. Phosphorus solubilizing bacteria: occurrence, mechanisms and their role in crop production. Resource and Environment Journal, Rosemead, v. 2, p. 80-85, 2012.

MURPHY, J.; RILEY, J. P. A modified single solution method for determination of phosphate in natural waters. Analytica Chimica Acta, Amsterdam, v. 27, p. 31-36, 1962.

NARAGHI L.; HEYDARI, A.; REZAEE S.; RAZAVI M. Biocontrol Agent Talaromyces flavus stimulates the growth of cotton and potato. Journal of Plant Growth Regulation, New York, v. 31, p. 471-477, 2012.

NAUTIYAL, C. S. An efficient microbiological growth medium for screening phosphate solubilizing microorganisms. FEMS Microbiology Letters, Amsterdam, v. 170, p. 265-270, 1999. 
NOVAIS, R. F.; SMYTH, T. J. Fósforo em solo e planta em condições tropicais. Viçosa, MG: Universidade Federal de Viçosa, 1999. 399 p. NUBEL, U.; ENGELEN, B.; FELSKE, A.; SNAIDR, J.; WIESHUBER, A.; AMANN, R. I.; LUDWIG, W.; BACKHAUS, H. Sequence heterogeneities of genes encoding $16 \mathrm{~S}$ rRNAs in Paenibacillus polymyxa detected by temperature gradient gel electrophoresis. Journal of Bacteriology, Washington, v. 178, p. 5636-5643, 1996.

OLIVEIRA, C. A.; ALVES, V. M. C.; MARRIEL, I. E.; GOMES, E. A.; MUZZI, M. R. S.; CARNEIRO, N. P.; GUIMARÃES, C.T.; SCHAFFERT, R. E.; SÁ, N. M. H. Phosphate solubilizing microorganisms isolated from rhizosphere of maize cultivated in an oxisol of the Brazilian Cerrado Biome. Soil Biology \& Biochemistry, Elmsfordv, v. 41, p. 1782 1787, 2009.

PEIX, A.; MATEOS, P. F.; RODRIGUEZBARRUECO, C.; MARTINEZ-MOLINA, E.; VELAZQUEZ, E. Growth promotion of common bean (Pasheolus vulgaris L.) by a strain of Burkholderia cepacia under growth chamber conditions. Soil Biology and Biochemistry, Elmsford, v. 33, p. 1927-1935, 2001 .

RAEDER, U.; BRODA, P. Rapid preparation of DNA from filamentous fungi. Letters in Applied Microbiology, Oxford, v. 1, p. 1720, 1985

RAJAPAKSHA, R. M. C. P.; HERATH, D.; SENANAYAKE, A. P.; SENEVIRATHNE, M. G. T. L. Mobilization of rock phosphate phosphorus through bacterial inoculants to enhance growth and yield of wetland rice.
Communications in Soil Science and Plant

Analysis, New York, v. 42, p. 301-314, 2011.

RICHARDSON, A. E.; BAREA, J-M.; MCNEILL,

A. M.; PRIGENT-COMBARET, C. Acquisition of phosphorus and nitrogen in the rhizosphere and plant growth promotion by microorganisms. Plant and Soil, The Hague, v. 321, p. 305-339, 2009.

RICHARDSON, A. E.; SIMPSON, R. J. Soil microorganisms mediating phosphorus availability. Plant Physiology, Washington, v. 156, p. 989-996, 2011.

RODRÍGUEZ, H.; FRAGA, R. Phosphate solubilizing bacteria and their role in plant growth promotion. Biotechnology Advances, New York, v. 17, p. 319-339, 1999.

SABER, W. I. A.; GHANEM, K. M.; EL-HERSH, M. S. Rock phosphate solubilization by two isolates of Aspergillius niger and Penicillium $\mathrm{sp}$. and their promotion to mung bean plants. Research Journal of Microbiology, New York, v. 4, p. 235-250, 2009.

SALE, P. W. G.; MOKWUNYE, A. U. Use of phosphate rocks in the tropics. Fertilizer research, Boon, v. 35, p. 33-45, 1993.

SCERVINO, J. M.; MESA, M. P.; MÓNICA, I. D.; RECCHI, M.; MORENO, N. S.; GODEAS, A. Soil fungal isolates produce different organic acid patterns involved in phosphat salts solubilization. Biology and Fertility of Soils, Berlin, v. 46, p. 755-763, 2010.

SCHRÖDER, J. J.; CORDELL, D.; SMIT, A. L.; ROSEMARIN, A. Sustainable use of phosphorus. Wageningen: Plant Resource International, 2010. $122 \mathrm{p}$.

SIMPSON, P. G.; SALE, P. W. G.; TENNAKOON, S. B. An economic analysis of the field 
performance of North Carolina reactive phosphate rock compared with single superphosphate for selected sites from the national reactive phosphate rock project. Australian Journal of Experimental Agriculture, Melbourne, v. 37, p. 1061-1076, 1997.

SINGH, H.; REDDY, M. S. Effect of inoculation with phosphate solubilizing fungus on growth and nutrient uptake of wheat and maize plants fertilized with rock phosphate in alkaline soils. European Journal of Soil Biology, Montrouge, v. 47, p. 30-34, 2011.

VAN STRAATEN P. Rocks for crops - Agro minerals of sub-Saharan Africa. Nairobi: ICRAF ; Guelp: University of Guelph, 2002. p. 338.

VAN STRAATEN, P. Farming with rocks and minerals: challenges and opportunities. Anais da Academia Brasileira de Ciências, Rio de
Janeiro, v. 78, p. 731-747, 2006.

VYAS, P.; GULATI, A. Organic acid production in vitro and plant growth promotion in maize under controlled environment by phosphatesolubilizing fluorescent Pseudomonas. BMC Microbiology, London, v. 9, p. 174-188, 2009.

WHITE, T. J.; BRUNS, T.; LEE, S.; TAYLOR, J. W. Amplification and direct sequencing of fungal ribosomal RNA genes for phylogenetics. In: INNIS, M. A.; GELFAND, D. H.; SNINSKY, J. J.; WHITE, T. J. (Ed.). PCR Protocols: a guide to methods and applications. San Diego: Academic Press, 1990. p. 315-322.

XIAO, C-Q.; CHIB, R-A.; HUANGB, X-H.; ZHANGC, W-X.; QIUA, G-Z.; WANGA D-Z.; Optimization for rock phosphate solubilization by phosphate-solubilizing fungi isolated from phosphate mines. Ecological Engineering, Oxford, v. 33, p. 187-193, 2008. 